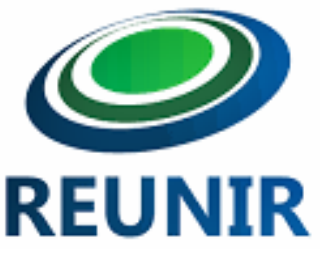

REUNIR:

Revista de Administração, Ciências Contábeis e

ARTIGO ORIGINAL

\title{
Forest deforestation in the Brazilian amazon states and its impacts on natural resources: construction of statistical-econometric panel model for 2000-2018 ${ }^{1}$
}

\author{
Desmatamento florestal nos estados da Amazônia brasileira e seus impactos sobre os recursos \\ naturais: construção de modelo estatístico-econométrico de painel para 2000-2018
}

\section{Deforestación forestal en los estados de la Amazonia brasileña y sus impactos sobre los recursos naturales: construcción de modelo estadístico-econométrico de panel para 2000-2018}

\author{
André Cutrim Carvalho ${ }^{2}$, David Ferreira Carvalho ${ }^{3}$ e Alana Paula de Araújo Aires ${ }^{4}$
}

\section{KEYWORDS \\ Deforestation. \\ Forests. \\ Natural resources. \\ Brazilian Amazon. \\ Panel Modeling.}

\begin{abstract}
In Brazil, deforestation in the Amazon is the main factor which is responsible for the destruction of natural resources and environment degradation. Economic growth and improving income distribution, for example, contribute to an increased demand for land and to the expansion of livestock production. Thus, in order to analyze the effects of economic growth and income distribution on natural resources, first it is necessary to distinguish the dynamics of the economic growth (whether slow or accelerated); and second, it is essential to know the form in which economic growth is taking place: whether through the extensive absorption of using factors of production; or whether through intense absorption with an increase in the productivity of the factors of production due to technical innovations; and third, the fact that the economy grows in a finite ecosystem implies an increase in opportunity costs. The effect of deforestation ultimately affects economic productivity and also provokes other ecological and socioeconomic disruptions. The aim of this paper is to analyze the impact of deforestation on the natural resources of the area known as Legal Amazon, during the period 2000-2018. For this, statistical-econometric instruments from panel modeling have been used. The central conclusion is that the main regressors associated with the rate of deforestation in the surveyed states continue to be the significant causes of this problem throughout the region. Thus, it is assumed that deforestation in the Amazon is, in fact, the main factor responsible for the destruction of natural resources. However, it cannot be denied that extensive livestock production continues to be the main activity responsible for the significant increase in deforestation in the region.
\end{abstract}

Resumo: No Brasil, o desmatamento da floresta da Amazônia é o principal fator responsável pela destruição dos recursos naturais do meio ambiente. 0 crescimento econômico e a melhoria na distribuição de renda pessoal, por exemplo, contribuem para o aumento da demanda por terras e expansão da pecuária. Desta forma, para analisar os efeitos do crescimento econômico e da distribuição de renda sobre os recursos naturais, torna-se necessário distinguir, em primeiro lugar, a dinâmica do crescimento econômico (lento ou acelerado); em segundo, conhecer a forma como o crescimento econômico está se processando: se pela absorção extensiva do emprego de fatores de produção; ou se pela
PALAVRAS-CHAVE

Desmatamento.

Floresta.

Recursos naturais.

Amazônia brasileira.

Modelagem em painel.

\footnotetext{
${ }^{1}$ Submetido em 23/04/2019. Aceite em 22/11/2019. Publicado em 30.05.2020. Responsável Universidade Federal de Campina Grande/UACC/PROFIAP/CCJS/UFCG 2 Doctorate in Economic Development at the Instituto de Economia at the Universidade Estadual de Campinas (UNICAMP). Professor at the Faculdade de Ciências Econômicas (FACECON) and on the Programa de Pós-Graduação em Gestão de Recursos Naturais e Desenvolvimento Local na Amazônia (PPGEDAM/NUMA) at the Universidade Federal do Pará (UFPA). E-mail: andrecc83@gmail.com, ORCID: https://orcid.org/0000-0002-0936-9424

${ }^{3}$ Doctorate and a Post-Doctorate in Economics at the Instituto de Economia at the UNICAMP. Professor at the Faculdade de Ciências Econômicas (FACECON) at the UFPA. E-mail: david.fcarvalho@yahoo.com.br, ORCID: https://orcid.org/0000-0002-9161-4715

${ }^{4}$ Economist and Master's degree by the Programa de Pós-Graduação em Gestão de Recursos Naturais e Desenvolvimento Local na Amazônia/Núcleo de Meio Ambiente (PPGEDAM/NUMA) at the UFPA. E-mail: alanah.aires@gmail.com, ORCID: https://orcid.org/0000-0002-6851-3107
} 
absorção intensiva com o aumento da produtividade dos fatores de produção devido inovações técnicas; e, em terceiro lugar, o fato da economia crescer em um ecossistema finito implica em aumento do custo de oportunidade. 0 efeito dos desmatamentos florestais acaba afetando a produtividade econômica e provoca outros transtornos de natureza ecológica e, também, socioeconômica. 0 objetivo do presente trabalho é analisar o impacto do desmatamento florestal sobre os recursos naturais da Amazônia Legal no período de 2000-2018. Para isso, o instrumental estatístico-econométrico oriundo da modelagem em painel foi utilizado. A conclusão central é que os principais regressores associados com a taxa de desmatamento florestal nos estados pesquisados continuam sendo importantes condutores desta problemática na região. Com isso, admite-se que o desmatamento florestal na Amazônia é, de fato, o principal fator responsável pela destruição dos recursos naturais. Contudo, não se pode negar que exploração de pecuária de corte em regime extensivo continua sendo a atividade predominante responsável pelo aumento significativo do desmatamento na região.

PALABRAS CLAVE Deforestación. Bosques. Recursos naturales. Amazonia brasileña. Modelado de paneles.
Resumen: En Brasil, la deforestación de la selva amazónica es el principal factor responsable de la destrucción de los recursos naturales del medio ambiente. $\mathrm{El}$ crecimiento económico y la mejor distribución del ingreso personal, por ejemplo, contribuyen a una mayor demanda de tierra y a la expansión del ganado. Por lo tanto, para analizar los efectos del crecimiento económico y la distribución del ingreso en los recursos naturales, primero es necesario distinguir la dinámica del crecimiento económico (lento o acelerado); segundo, saber cómo se está produciendo el crecimiento económico: ya sea por la absorción extensiva del empleo de factores de producción; o si por la absorción intensiva con el aumento de la productividad de los factores de producción debido a innovaciones técnicas; y tercero, el hecho de que la economía crezca en un ecosistema finito implica mayores costos de oportunidad. El efecto de la deforestación afecta la productividad económica y causa otras perturbaciones ecológicas y socioeconómicas. El objetivo del presente trabajo, por lo tanto, es analizar el impacto de la deforestación forestal en los recursos naturales de la Amazonía Legal en el período 2000-2018. Para esto, se utilizaron los instrumentos estadístico-econométricos del modelo de panel. La conclusión es que los principales regresores asociados con la tasa de deforestación en los estados encuestados continúan siendo importantes impulsores de este problema en la región. Por lo tanto, se supone que la deforestación en la Amazonía es, de hecho, el principal factor responsable de la destrucción de los recursos naturales. Sin embargo, no se puede negar que la ganadería extensiva sigue siendo la actividad predominante responsable del aumento significativo de la deforestación en la región. 


\section{Introduction}

In Brazil, deforestation in the Amazon is the main factor responsible for the destruction of natural resources and of environmental degradation. Economic growth and improved income distribution both contribute to the increased demand for land in order to produce Nellore beef cattle. Thus, in order to analyze the effects of economic growth and income distribution on natural resources, first it is necessary to distinguish the dynamics of the economic growth (whether slow or accelerated); and second, it is essential to know the form in which economic growth is taking place: whether through the extensive absorption of using factors of production; or whether through intense absorption with an increase in the productivity of the factors of production due to technical innovations; and third, the fact that the economy grows in a finite ecosystem implies an increase in opportunity costs.

Within this context, additional costs are derived from the fact that forest fires constitute a structure that dissipates heat supported by metabolic flow from the depths of the environment. The production flow of goods, in turn, begins with the removal of natural resources from a low environmental entropy and continues into the processes of production and consumption of goods, ending with the return of a determined equivalent amount of high entropy polluting waste, which as resulted from the destruction of natural resources.

By the first law of thermodynamics, the law that conserves material and energy, production is subject to an equilibrium equation: i.e., input equals output plus accumulation. If accumulation occurs, there is a tendency for the economic subsystem to grow. In a state of equilibrium, however, growth and accumulation would be zero, input flow would be equal to output flow.

In other words, all raw material inputs would become waste outlets. As a consequence, there are two end results to production: the depletion of environmental sources; and the pollution of environmental deposits. Thus, to ignore production is to ignore depletion and pollution. Therefore, unlike exchange value, the flow of production is not circular; it is a univocal flow from low entropy sources to high entropy deposits.

This is a consequence of the Second Law of Thermodynamics, the law of entropy. We are able to recycle materials, but never completely. Recycling is a flow in the opposite direction to the circular flow. Energy, according to the law of entropy, is not recyclable in a state of nature without human action. However, clearly, it is recyclable by human action, and yet, for this, more energy is required to recycle than the amount that may be recycled. In fact, recycling energy is not physically impossible, but it is always an economic waste - regardless of the price of energy.

It should be noted that all production begins with the depletion of natural resources with low environmental entropy; and is followed by the processes of production, distribution and consumption. It should be highlighted however, that the processes of manufacturing and transportation are physical transformations and also of displacement in space, since they end with the return of a determined equivalent amount of high entropy polluting waste.

The aim of this paper therefore, is to analyze the impact of deforestation on the natural resources in the Brazilian Amazon between 2000-2018. It is assumed that deforestation in the Amazonian states is the main factor responsible for the destruction of natural resources.

That said, the pace of deforestation in the Brazilian Amazon states is associated with the following causes: the product growth; the population quota; the deforested area; and the income distribution of the population. For this, the article has been structured into seven sections, besides this introduction and the last section with the final considerations: the second section presents the methodological aspects of the work; the third defines the concepts of mode of production and mode of extraction in terms of the discussion on natural resources; in the fourth section the debate revolves around deforestation in order to create pasturelands in the Brazilian Amazon; and the fifth section is the step-by-step procedure for constructing and using the statistical econometric panel model for deforestation in the region. The final section presents an analysis of the results of the statistical-econometric panel model.

\section{Theoretical elements of research}

\section{Mode of production and mode of extraction: a necessary} understanding

The first step towards aproper analysis of the coevolution of a regional social formation requires us to cast off any notions that are only relevant to industrial production systems. Under these conditions (certain) concepts derived from the European experience of the accumulation of capital and technological innovations in industrial production still provide the mathematical basis for analyzing industrial and non-industrial economies.

However, Georgescu-Roegen (1969) argued that economic models of industrial production neglect the origins of raw materials transformed by urban industry. In fact, the internal dynamics of the extractive economies that supply most commodities exported from developing countries to developed countries differ from productive economies in terms of how they affect the natural environment, population distribution, income distribution, economic infrastructure and, therefore the potential economic development of the affected extractive regions.

Relations between nations that have natural resources under or on their lands and waters and that turn natural resources into useful products have some of the most intense theoretical debates. The reason for this is basically simple: when the economies of industrial societies expand, they discover, sooner or later, that it is only possible to continue the economic activity if it is possible to import raw materials from outside the limits of their borders.

Industrialists know that they need a stable supply of raw materials for their manufacturing plants; and that their profits are usually high if the cost of raw materials is low. Thus, the governments of industrial societies know that economic growth and military security depend on trust and a cheap supply of raw materials.

Bunker (1985) developed the concepts of mode of extraction and mode of production so as to suggest the systemic connections between the industrialized regions of the centers and the extractive regions of the peripheries. He argued that industrial production models do not lend themselves to explaining the internal dynamics of extractive economies because the exploitation of natural resources uses and destroys values in energy and material that cannot be calculated in terms of labor or capital. 
When natural resources are extracted from one regional ecosystem to be transformed and consumed in another, the exporting region loses value generated in its physical environment. These losses eventually slow down the economy of the extractive region, while consuming communities gain value and accelerate their economies. In this case, the appropriate model of interaction between the global economy and the regional economy must account for the differences and independence between the two systems.

Bunker (1985) also observed that the development of an extreme periphery region results from the organization, coordination and utilization of human and non-human energies as well as the distribution of derived and transformed productive resources in the region or traded by resources derived or transformed in other regions. Thus, the human uses of a regional environment depend on the characteristics of its ecosystem.

These characteristics are formed in part by earlier uses and deliberate human transformations. Therefore, social organization, which may either accentuate or limit access, and the useful transformation of natural resources, is delimited and modelled more towards these ecosystems. Indeed, the differences between the internal dynamics of the extraction model and of the production models create an unequal exchange, not only in terms of the labor value embodied in the products, but also in the amount of differences and interdependence between these two systems.

It is important to understand that appropriation and ecological results affect social class structures, the organization of labor, exchange and property systems, the form with which to develop government activities, income distribution, population distribution, the development of economic infrastructure and, particularly, the various kinds of information, beliefs, and ideologies that shape social organization and behavior.

Another relevant aspect that differentiates the mode of extraction from the mode of industrial production is related to the location of productive companies, generally close to one another. This generates external savings in the sense that their costs are shared amongst the various productive companies. Extractive companies are often located very close to the natural resources that they intend to exploit.

Natural resources are randomly distributed in relation to production centers, and because of this proximity to other businesses occurs only by chance, and this becomes less likely as more accessible natural resources are depleted. Extractive economies rarely benefit from the spatial and productive continuities of other pre-existing companies and the infrastructure of exploration sites is rarely shared, as reported by Bunker (1985).

Development theories have focused on processes of industrial production, however, they have not recognized the dependence of developed economies on the natural resources of extractive regions of supply. Industrialists know that they need a stable supply whatever the raw material their factories transform; and that their profits will generally be higher if the cost of raw materials is, a priori, much lower.

Furthermore, Bunker and Ciccantell (1994) argue that because many of the raw materials critical to industry are only located in certain parts of the world; or because of changes in the quantity and quality of specific natural resources in different places, industrialized nations may compete with one another in various ways to ensure control of or access to specific natural resources in specific resource-rich countries.

Another aspect of economic growth refers to the impacts of human action on natural resources and the environment in border regions in the process of human occupation - such as the Amazon. For Carvalho (2012, p. 25):

"The economic frontier, in this case, is the territorial locus of an economy in the process of nationally forming and integrating its productive structure of goods and services within the internal limits of a nation" 5 .

process of human occupation progresses, so there is a quantitative and qualitative destruction of natural resources. This requires human action for the necessary adaptation of shared evolution between the economy and the ecosystem. If this adaptation is made in partnership with nature and within the limits of the ecosystem's natural capacity to absorb waste and regenerate natural resources, then the scale of economic occupation presupposes the principles of sustainable development, as determined by Daly and Farley (2004).

It may be perceived that economic growth depends on investments in productive capital, human capital, economic infrastructure, and the quality of productive and natural resources. A nation's economic growth is not distinguished by any modifications to the participation of sectors in the total product and in the productive resources used, but rather before this, by the speed and breadth of the structural changes when they continue to exist for decades. Within this context, Kuznets (1974) argued that the three basic sectors - agriculture, industry and services - differ significantly with respect to the use of natural resources, to the operational scale of the productive units common to the production process employed, and in the final product with which they contribute to their participation in the final product and in the resources employed. Thus, the depletion of exploited natural resources leads to the impoverishment of local populations.

Altvater (1995), for example, adapted the concept of syntropy from physics to social sciences. Syntropy refers to the state of a high order (closed) social system, i.e., a state of low entropy. The concept of syntropy is preferred to entropy simply because the latter refers essentially to energy flows, or rather, the conversion of free energy to bound energy.

The people from the traditional communities in the Amazon region, most notably the riparian and forest peoples, live in a state of social syntropy with low entropy, corresponding to a minimum destruction of the environment, because the main economic activity of these people is extractivism. However, as from the moment when people living in these communities change this pattern of economic activity to agriculture or livestock, they are induced towards the practice of deforestation and burning, which leads to the destruction of natural resources, the environment and biodiversity. This contributes to an increase in entropy and, consequently, a reduction in syntropy.

Moreover, Kolstad (2000) has warned that the risk and uncertainty factors in the environment must be taken into account whenever a production decision implies the exploitation of natural resources, the economic, social and environmental impacts of which are unknown. 


\section{Methodological elements of the research}

Methodological specification is a mandatory part of any academic research that adopts a scientific method. However, it is necessary to distinguish the approach method from the said research methods. The method of approach is concerned with the philosophical affiliation to and the degree of abstraction from the studied phenomenon, while the research methods or research procedures, involve the concrete steps of the investigation and the use of appropriate research techniques.

In the social sciences in general, particularly in the economic sciences, a methodological restriction is imposed: which is the need to confront the considered reality, abstracted from the concrete, with the empirical reality, i.e., that which is perceived by our senses. In turn, as noted by Lakatos and Marconi (1991, p. 106), "practical knowledge is subject to the need for immediate connection with the reality to which it refers."

In theoretical research, unlike empirical research while the research method is based on field surveys of primary data or even on surveys of secondary data - the research method has more to do with the method of exposing ideas: either deductive or inductive.

Under these conditions, the method used in this paper involves the deductive method, since it starts from the general, i.e., the discussion involving the theoretical foundations for understanding the dynamics of deforestation in the Amazon rainforest; and also the inductive method, because it considers the specific, the role of natural resources as a fragile element within this relationship. As the purpose of this paper is to characterize their role, this research may be defined as exploratory. For Gil (1991) apud Da Silva and Menezes (2005, p. 83):

[A] Exploratory Research aims to provide greater familiarity with the problem in order to make it explicit or to build hypotheses. It involves bibliographic survey; (...) analysis of examples that promote understanding. It generally takes the forms of Bibliographic Research and Case Studies.

In addition, the present research project will seek as much information as possible on these important subjects using the qualitative research technique, which aims to broaden information on the subject through books, journal articles and other important references. According to $\mathrm{Da}$ Silva and Menezes (2005, p. 20):

[Qualitative research] considers that there is a dynamic relationship between the real world and the subject, i.e., an inseparable link between the objective world and the subjectivity of the subject that cannot be translated into numbers. In the qualitative research process, the interpretation of phenomena and the attribution of meanings are basic.

However, because this work uses statisticaleconometric instruments from panel models, the research will also be quantitative. In the words of $\mathrm{Da}$ Silva and Menezes (2005, p. 20):

[Quantitative research] considers that everything may be quantifiable, which signifies translating opinions and information into numbers so as to classify and analyze them.
This requires the use of resources and statistical techniques (percentages, means, modes, medians, standard deviation, correlation coefficient, regression analysis, etc.).

Thus, in terms of the approach employed for the problem, this will be a quali-quantitative research.

\section{Deforestation for conversion into pasture in the Brazilian Amazon}

Forests that now occupy more than a quarter of the earth's surface fall into three categories: wet or dry tropical forests, temperate forests and degraded forests. Clearing forests by burning is the source of air pollution (due to smoke clouds, which may cause respiratory disease in humans), soil degradation (including erosion), changes in the hydrological and climate cycles and destruction of biodiversity.

Within this context, the effect of deforestation on the region ultimately affects economic productivity and causes other ecological disturbances. However, amongst the factors involved in the deforestation of vegetation cover, the most concerning is that wet tropical forests are disappearing at a rate that endangers their economic and ecological functions. With an area of over 1.5 billion hectares, according to data from the Food and Agriculture Organization of the United Nations - FAO (2013), wet tropical forests have the richest biomass and biodiversity ecosystems in the world.

Around two thirds of wet tropical forests are in Latin America, mostly in the Amazon basin, and the remainder are in Africa and Asia. Dry tropical forests, which cover an area of 1.5 billion hectares, are located in Africa and Oceania. Temperate forests total about 1.6 billion hectares, three quarters of which are in industrialized countries, according to the World Bank (1992).

In general, deforestation is caused by farming, livestock production, logging, mining activities, charcoal and firewood production, each targeting their own particular interests, which are often distorted by misguided public policies. In the case of the states in the Brazilian Amazon, the pace of accelerated deforestation both for converting into pasture and because of logging activities, has been a matter of great concern to the federal government, the Brazilian population and the international community.

Deforestation in the wet tropical forests of the Brazilian Amazon in order to convert into pastures and to cultivate agricultural products has become common practice ever since the mid-1960s. Indeed, as Carvalho determined $(2012,2017)$, it may be said that it was "Operation Amazon" that defined an occupation strategy over an area termed Amazônia Legal ${ }^{6}$, and also foresaw the institutions that would later be created by the federal government -the Superintendency of Development for the Amazon (SUDAM), the Bank of Amazonia S/A (BASA) and The National Institute for Colonization and Land Reform (INCRA), which would be responsible for implementing the new occupation and development policies, as well as the necessary instruments of regional development policy (fiscal-financial incentives, bank credit and land legalization) to enable the penetration of capital under the aegis of the military government. 
This institutional apparatus, from a historical viewpoint, contributed towards the increase in the rate of deforestation and to the formation of pasture throughout the states of the Brazilian Amazon. The encouragement of extensive live stock production and the construction of the great penetration highways were the vectors created by the federal government for implementing the Amazon occupation policy through a project known as pata do boi (the hooves of the bull). Between 1980-2000, increasing criticism against this occupation policy in Amazônia Legal, based on livestock production, led to the end of tax incentives and the extinction of SUDAM, which was replaced by the Amazon Development Agency (ADA) under the government of (former) President Fernando Henrique Cardoso. ${ }^{7}$ Nevertheless, under pressure from the regional oligarchies SUDAM was resurrected during the government of (former) President Luiz Inácio Lula da Silva.

The main points of criticism were the following: low employment and income, increased rural violence triggered by land speculation as "reserves of value", increased rates of compulsory labor and the destruction of natural resources through deforestation of the Amazon to create pasture.

Nonetheless, even with the end of the tax incentive policy, the pace of deforestation for conversion into pasture continued to accelerate, and became a point of concern for the federal government and international agencies, such as the World Bank.

However, between 1995-2015, the dynamics of deforestation in the Brazilian Amazon gained new contours. Indeed, unlike the previous period of 1965-1995, when occupation of the region had been stimulated through fiscalfinancial incentives and other federal government policies, the reality during this period revealed other motivations for increasing the pace of deforestation in the Brazilian Amazon.

Currently, deforestation is autonomously conducted by cattle ranchers and loggers, i.e., without the past financial support of the tax incentive policy. Nowadays, extensive beef cattle production, logging and indiscriminate mining, in the current conjuncture, make up the activities that are responsible for the high rates of deforestation across the region. However, there is little doubt that extensive beef cattle production is the main activity responsible for the increase in the rates of deforestation in the Amazon rainforest, especially in the states of Pará and Mato Grosso.

Growth dynamics of extensive beef cattle production as a driving force behind deforestation in the Brazilian Amazon

Extensive livestock production is an economic activity that requires some specialization, with regard to the type of herd, which is to be reared. Thus, the division of labor implies different phases of beef cattle production: the breeding, rearing and fattening phases. In the state of Pará, for example, the breeding system is extensive and the practice of rational management of grazing cattle subdivided into grazing units is still lacking.

According to Carvalho and Lopes (2017), on farms, with no appropriate rural infrastructure, cattle are very often distributed across large areas of poorly divided pastures, with no rational distribution of breeders (bulls and cows), their calves (male and female) and of adult animals (bulls

7 SUDAM became extinct on $2 / 3 / 2001$. ADA was created in August 2001, although it only began to function on $27 / 3 / 2003$. The new SUDAM was and heifers) in order to allow the rational management of livestock. However, there have been a number of improvements in complementary diet and the practice of mineral salt supply.

Beef producing farmers are able to trade their young bulls and heifers with other farmers, who are only involved in the rearing phase, in order to resell to those who specialize in fattening cattle for sale to slaughterers, refrigerated abattoirs and meat agro-industries that, in turn, target meat prepared for retail consumption.

However, recently, exports of live cattle have begun to Arab countries. Nonetheless, sometimes, the same producer, depending on the location of the farm in relation to the consumer market, may integrate the breeding, rearing and fattening phases of cattle, thereby achieving horizontal integration. According to Carvalho (2012), agricultural planning, introduced by SUDAM in the analysis of projects, that received monetary resources from the fiscal-financial incentive policy, has enabled the transformation of traditional livestock production into large-scale livestock corporations, both in size and investment.

Recently, the National Institute for Space Research (INPE), through the Brazilian Satellite Monitoring Program of Deforestation in Legal Amazon (PRODES), released a comparison of the 2017 and 2018 deforestation rates, as presented in Table 1.

Table 1 - A comparison of the deforestation rates: 2017-2018

\begin{tabular}{l|c|c|c}
\hline States & $\begin{array}{c}\text { PRODES } \\
2017\left(\mathrm{Km}^{2}\right)\end{array}$ & $\begin{array}{c}\text { PRODES } \\
2018\left(\mathrm{Km}^{2}\right)\end{array}$ & $\begin{array}{c}\text { Variation } \\
(\%)\end{array}$ \\
\hline Acre & 257 & 444 & 73 \\
\hline Amazonas & 1,001 & 1,045 & 4 \\
\hline Amapá & 24 & 24 & 0 \\
\hline Maranhão & 265 & 253 & -5 \\
\hline Mato Grosso & 1,561 & 1,490 & -5 \\
\hline Pará & 2,433 & 2,744 & 13 \\
\hline Rondônia & 1,243 & 1,316 & 6 \\
\hline Roraima & 132 & 195 & 48 \\
\hline Tocantins & 31 & 25 & -19 \\
\hline \multicolumn{1}{c|}{ Amazônia Legal } & 6,947 & 7,536 & 8 \\
\hline
\end{tabular}

Source: INPE/PRODES (2019)

Figure 1 - Annual deforestation rates in Amazonia Legal

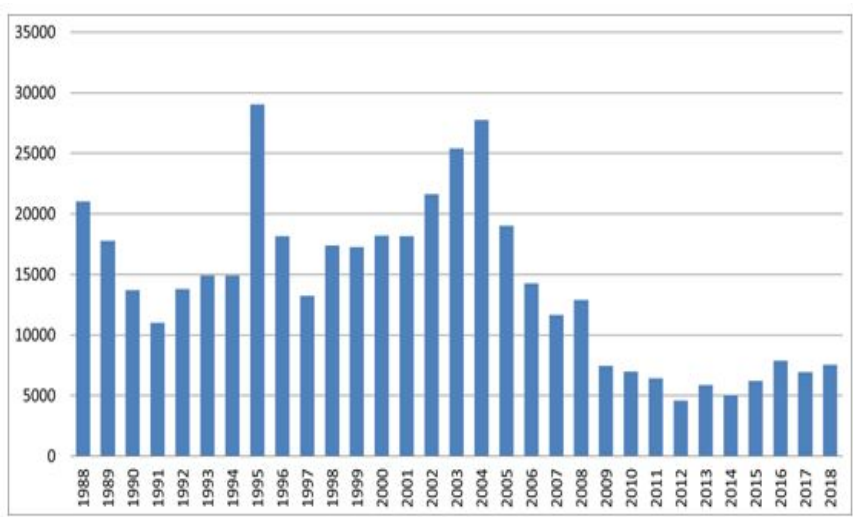

Source: INPE/PRODES (2019)

The data in Table 1 indicate that the states of Pará and Mato Grosso remain the biggest representatives of this stain on the region. Further significant data is contained in Figure

definitively created through Complementary Law $n^{\circ} 124$, on $3 / 1 / 2007$. See Lira (2007). 
1, which demonstrates the historical series from PRODES for Amazônia Legal from 1988 to 2018 with, once again, the states of Mato Grosso and Pará a head in the deforestation ranking.

It would appear that this model of extensive livestock production has not yet become a true animal agribusiness. Under these circumstances, extensive beef cattle production remains an activity with a low degree of vertical integration, with the export of low economic value added products and, in a decisive manner, for being chiefly responsible for deforestation in the states of the Brazilian Amazon.

In terms of statistical data, Table 2 demonstrates the effective growth of cattle herds in Amazonia Legal during the period 2000-2018.

Table 2 - Effective growth of cattle herds in the state of Amazônia Legal

\begin{tabular}{l|c|c}
\hline States/Year & 2000 & 2018 \\
\hline Acre & $1,033,311$ & $3,017,291$ \\
\hline Amazonas & 843,254 & $1,376,210$ \\
\hline Amapá & 82,822 & 55,422 \\
\hline Maranhão & $4,093,563$ & $7,793,180$ \\
\hline Mato Grosso & $18,924,532$ & $30,199,598$ \\
\hline Pará & $10,271,409$ & $20,628,651$ \\
\hline Rondônia & $5,664,320$ & $14,367,161$ \\
\hline Roraima & 480,400 & 817,198 \\
\hline Tocantins & $6,142,096$ & $8,352,513$ \\
\hline Amazônia Legal & $35,145,164$ & $86,607,244$ \\
\hline
\end{tabular}

Table 2 indicates that the states of Para and Mato Grosso presented a substantial growth during the period 2000-2018. Much of this is due to an increase in the international demand for beef and also, because of an increase in the domestic consumption of Brazilian beef, as confirmed in the data from the Municipal Livestock Research (PPM), linked to the Brazilian Institute of Geography and Statistics (IBGE).

\section{Economic growth and the impacts on natural resources: a literature review}

Economic growth may impact on the natural resources of a region during the process of occupation. The environment is often used to represent all the chemical, biological, ecological and geographical systems on a local, regional, national and even global scale. These systems may be degraded in many different ways, but it is human activities, which are primarily responsible for the impacts on our natural resources, both directly and indirectly. For example, there is evidence that some animal species have been hunted into extinction.

The elements that influence the configuration of who (which social groups) has more or less influential force on the markets and what is demanded by these groups are called the dynamic factors of the pattern of development. These factors include product growth, the per capita income, the distribution of wealth and income, employment opportunities, the tastes and preferences of those with the highest income to support demands; and the habits and preferences of products imported from abroad, as viewed in Muller (2007).

The main factors determining the effects of human activities on natural resources, a priori, are related to economic growth, the size of the population, the size of the deforested area, per capita income, technology, culture, institutions, income level and distribution. Long-term economic growth depends on income distribution, thus economic growth and income distribution change over time, as determined by Nikiforos (2014). Indeed, studies by authors such as Day and Grafton (2001) highlight the challenges facing developed and developing countries and are directly linked to global climate changes, ozone depletion, ecosystem integrity, natural resource degradation, and the incidence of deaths and diseases due to the degradation of natural resources.

Moreover, the environment provides the following benefits: ecological services and natural resources for the production of goods and an assimilation capacity to break down waste and to regenerate renewable natural resources.

Within this conjuncture, human activity uses natural resources in the production of goods in order to produce a flow of goods released onto the market, whereby the feedback process exists in each of them, including recycling the waste left by consumers, as determined by Grafton et al. (2004). In fact, essentially through research conducted by authors such as Mishan (1969), Commoner (1972) and Solow (1975), the impacts of deforestation on natural resources have been tested by panel models, and have confirmed the undesirable impacts of deforestation on natural resources.

The panel statistical-econometric model is characterized by the use of data available at a point in time, for example in a given year. Panel econometric models combine time series data with cross-sectional data. The main advantage of using panel data is to increase the degree of accuracy in estimating parameters and coefficients. This advantage results from increasing the number of observations by combining each of the individual entities over various periods of time.

However, validating statistical inferences involves having to control the probable correlation of the error terms of each individual over time. An independent grouping of cross-sectional data is obtained by randomly sampling a large population over different time periods -and not single sampling and not necessarily over different years - which could lead to non-identically distributed observations.

Independent cross-sectional clustering data have an important statistical feature: they do not derive from observations of independently collected samples, and this eliminates the error correlation between the different observations, as observed by Wooldridge (2006).

Panel clustering often gathers time series and crosssectional data. However, although panel clustering gathers both time series and cross-sectional dimension data, it differs in certain respects from the independent crosssectional clustering data. Panel data collection, known as longitudinal data, is performed through random sampling from the same group of individuals, families, companies, cities, states, countries, or any other entity over time.

Thus, multiple panel regressions are based more on short period panel data than on long period panel data and consist of few entity cross-sectional data observed over many time periods (Cameron and Trivedi, 2005); (Wooldridge, 2010).

In panel econometric models when data are not available for some of the variables of a multiple panel regression, these variables cannot be included in the panel econometric regression and the estimators of the ordinary least squares (OLS) of the multiple regression coefficients 
may present a bias by omitting variables. However, it is possible to use a control method over certain types of omitted variables without actually observing them. This method requires a special type of data in which each sample observation unit (entity) is considered in two time periods (Stock and Watson, 2004).

There are two types of panel econometric models: a) the balanced panel data econometric model that includes all observations, i.e., the variables are observed for each entity and each period; and b) the unbalanced panel data model that implies a panel with missing cross-sectional data.

The advantage of panel data over cross-sectional data is that the panel model allows the researcher greater flexibility with regard to the behavior of the differences in cross-sectional individuals.

However, this panel econometric model (1) is very generic and is not estimable when there are more parameters than observations to estimate. In addition, restrictions must be placed on the extension to which the parameters $B_{i t}$ and $B_{1 i t}$ vary with $i$ and $t$; and by restrictions on the error terms of $u_{i t}$.

In such a panel model, may be consistently estimated, and by the same token, ( $\mathrm{T}-1)$ dummy variables may be included in the $x_{i t}$ regressors. The challenge, argues Greene (1997), is to estimate the values of the $B_{i}$ parameters by controlling the individual intercepts $a_{i}$.

The statistical-econometric specification of the basic panel model

The basic structure of a panel regression statisticaleconometric model may be represented as follows:

$$
y_{i t}=\beta_{i t}+\sum_{k=2}^{k} \beta_{k i t} x_{k_{i t}}+u_{i t}
$$

In which:

$y_{i t}=y_{i t}=$ represent the dependent variables in each cross-section i in the period $t$;

$x_{\text {kit }}=$ represent the explanatory variables of each unit of the cross-section $i$ in the period $t$;

$B_{\text {kit }}=$ represent the different intercepts of each unit of the cross-section $i$ in the period $t$;

\section{$\mathrm{u}_{\mathrm{it}}=$ error terms}

Basic panel regression model (1) is very generic and is not estimated when there are more parameters than observations. It is also necessary to place restrictions on the extent to which the parameters $B_{1 i t}$ and $B_{2 i t}$ vary with $i$ and $t$; and place restrictions of the behavior of the error terms $\mathrm{u}_{\mathrm{it}}$.

In the panel regression model (1) the dependent variables $\left(y_{i t}\right)$ may be consciously estimated and the dummy $(T-1)$ variables may be included in the explanatory variables $\mathrm{X}_{\mathrm{it}}$.

The challenge is to estimate parameter values $B_{i}$, while controlling the individual interceptors $a_{i}$. By taking the values of $a_{i}$ as being the same for all cross-sections, the ordinary least squares (OLS) provide efficient and consistent estimations of $a_{i t}$ and $B_{i t}$.

One alternative manner with which to use panel data in an econometric panel model is to separate the unobserved data that may affect the regressed variable into two types of factors: 1) the constant factors and the variable factors over time. Most restrictive models result in a combined cross-sectional econometric model that specifies the intercept and coefficients of the explanatory variables as in the hypothesis of cross-section regression analysis, such that:

$$
y_{i t}=\alpha_{i}+\beta_{i} x_{i t}^{\prime}+u_{i t}
$$

In which $a_{i}$, for example, is a constant.

If the panel model is correctly specified so that the regressors are uncorrelated with idiosyncratic error terms or compositional times, then these models may be estimated using a combination of OLS.

However, it is likely that the error terms will be correlated over several time periods for an entity. Given this, the combined OLS estimator is inconsistent if the fixed effects regression model is appropriate. Thus, by including dummy variables, we obtain:

$$
y_{i t}=D \alpha+X^{\prime} \beta+u_{i t}
$$

Where:

$\mathrm{D}=\left[d_{1}, d_{2} \ldots . d_{n}\right]$

With $\mathrm{d}_{\mathrm{i}}$ the $d_{i}$ dummy variable dummy with the itch observation unit $(i=1,2, \ldots n)$.

The panel regression model ( 3 ) is known as the dummy variable model (DVM). In this case, the estimator is expressed by $\hat{\beta}_{i t}=\left[X^{\prime} M_{d} y\right]^{-1}\left[X^{\prime} M_{d} y\right]$, where the diagonal matrix is given by $M_{d}=1-D\left(D^{\prime} D\right)^{-1}$ (Greene, 1997). In this case, the Chow test is recommended, which compares the sums of the squares of the estimated residues in their restricted and unrestricted forms.

\section{The statistical-econometric specification of the fixed} effects panel model

The first differentiation is a method of eliminating the fixed effect, $a_{i}$. Another method is known as fixed effect transformation. In this case, the fixed effects panel template is expressed as follows:

$$
\begin{aligned}
& \hat{y}_{i t}=\sum_{i=1}^{n} \beta_{1 i t} D_{k t}+\sum_{i=2}^{k} \beta_{k} \hat{x}_{i t}+\hat{u}_{i t} \text { (4) } \\
& \text { Thus: } \\
& D_{k t} D_{k t}=\text { are the dummy variables; } \\
& \hat{y}_{i t}=y_{i t}-\hat{y}_{i} \hat{y}_{i t}=\text { are the reduced time data of } \mathrm{y} \text { and, of }
\end{aligned}
$$

$$
\text { the analogue manner, } \hat{x}_{i t} \text { and } \hat{u}_{i t} \cdot \hat{u}_{i t}
$$

Statistical-econometric specification of the random effects panel model

The random effect panel model is represented as:

$y_{i t}=\beta_{0}+\beta_{1} x_{i t 1}+\cdots . .+\beta_{k} x_{i t k}+\alpha_{i}+u_{i t}$

Where: $\mathrm{t}=1,2, \ldots \mathrm{T}$.

Random panel models include the intercept to assume that the unobserved effect, $a_{i}$, have a mean value of zero. Normally, dummy variables are included amongst the observed explanatory variables.

The random effect panel model (5) becomes a random effect panel model when the unobserved effect, $\alpha_{i}$, is assumed, and is uncorrelated with each explanatory variable, which signifies that:

$$
\operatorname{Cov}\left(x_{i t j}, \alpha_{i}\right)=0 \text {, in a manner that }=1,2, \ldots, \mathrm{T} ; \text { e } \mathrm{j}=
$$
$1,2,3, \ldots ., \mathrm{k}$

In fact, the hypotheses of the random effects panel model include the hypotheses of the fixed effects panel model assumptions plus the additional requirement that $a_{i}$ should be independent of the explanatory variables in the time periods of the series (CAMERON and TRIVEDIM, 2007).

If it is identified that the unobserved effect $\alpha_{i}$ correlates with any of the explanatory variables, then either the first differentiation method or the fixed effects panel method should be used. However, if the composite error 
term is identified, such that, $v_{i t}=\alpha_{i}+u_{i t}$, so random effects panel model (5) may be rewritten as follows:

$$
y_{i t}=\beta_{0}+\beta_{1} x_{i t 1}+\cdots_{. .}+\beta_{k} x_{i t k}+v_{i t}
$$

In which:

$$
\sigma_{i t}^{2}=\operatorname{Var}\left(\alpha_{i t}\right) \text { e } \sigma_{u}^{2}=\operatorname{Var}\left(u_{i t}\right)
$$

This necessarily positive serial correlation in the error term may be substantial since the usual clustered OLS standard errors ignore this correlation. In this case, they are incorrect, as are the test statistics, unless the generalized least squares (GLS) regression model is used.

For this intended procedure to have good properties, $\mathrm{N}$ must be large and $\mathrm{T}$ relatively small. In this case, it is assumed that the panel model is in equilibrium or otherwise nonequilibrium. Statistical tests for comparison between Fixed Effects (FE) and Random Effects (RE) can be tested by the Hausman test (1978), which is considered the most appropriate for this purpose.

The Hausman test is based on the difference between the estimates of the fixed and random effects, such that:

$$
\mathrm{H}=\left(\delta_{E F}-\delta_{E A}\right)^{\prime}\left[A v \hat{a} r\left(\delta_{E F}\right)-A v \hat{a} r\left(\delta_{E A}\right)\right]^{-1}\left(\delta_{E F}-\delta_{E A}\right)
$$

Thus, $\delta_{E A}$ denotes the vector of the random effects that are estimated without the coefficients of the time constant or the aggregate variables; and $\delta_{E F}$ denotes the estimated vector of the fixed effects, both vectors are $M \times 1$. If the $\mathrm{FE}$ are consistent when there is correlation, but RE are inconsistent, then any statistically significant difference should be interpreted as evidence against the hypothesis of specific random effects of uncorrelated entities with regressors. Even if such correlations persist, it may be possible to estimate a random effects model using methods with instrumental variables.

\section{Presentation and discussion of results}

\section{Analysis of the results of the statistical economic panel model}

Firstly, it is necessary to understand that panel data results from a combination of time-series data and crosssectional data. In general terms, the fundamental motivation for using panel data is in solving problems in the omitted variables.

The advantage of panel data is the increased accuracy of the estimation. The data sources used to construct the statistical-econometric panel models are from the following departments: Brazilian Institute of Geography and Statistics (IBGE); Institute for Applied Economic Research (IPEA) and National Institute for Space Research (INPE). The data used in the panel model originate from the Amazonian states of Acre, Amapá, Amazonas, Pará, Rondônia, Roraima and Tocantis.

The years of the panel data are from 2000-2018. The dependent variable of the panel model is the deforestation rate in the Amazon (DeforestRate_AMAZ) expressed in $\mathrm{km}^{2} /$ year. The explanatory variables determining the annual deforestation rate in the Amazon are: the gross domestic product (GDP) of the states in the Brazilian Amazon (GDP_AMAZ) expressed in monetary terms; the size of the population of the Amazonian states expressed in the number of inhabitants (POP_AMAZ); the deforested area of the Amazon (AreaDef'd_AMAZ) expressed in $\mathrm{km}^{2}$; and the cattle herd (CattHerd_AMAZ) as a proxy of the beef production.

\section{Analysis of the regression results of the fixed-effects statistical-econometric panel model}

Table 3 demonstrates that the partial regression coefficients of the fixed-effects statistical-econometric panel model are statistically different from zero ata $5 \%$ probability of error.

Table 3 - Regression Results of the Fixed Effects Panel Model

Dependent variable: DeforestRate_AMAZ

Method: Fixed effects panel using 8 observations

\begin{tabular}{|c|c|c|c|}
\hline Explanatory Variables & Coefficients & T-test & P-value \\
\hline Constant & 4.42581 & 13.43 & $0.0080^{* * *}$ \\
\hline GDP_AMAZ & 0.012813 & 17.03 & 3.114 \\
\hline POP_AMAZ & 0.040970 & 19.64 & 2.307 \\
\hline AreaDef'd_AMAZ & 0.035297 & 19.71 & 1.884 \\
\hline CattHerd_AMAZ & 0.031135 & 11.13 & 1.875 \\
\hline $\begin{array}{l}\text { The Mean Dependent Variable }=4.5 \\
\text { Residual Sum of Squares }=1.296482 \\
R^{2} \text { LSDV (least-squares dummy variables) }= \\
F(5,8) \text { LSDV }=5.99 \\
\text { Log-Likelihood }=-4.07236 \\
\text { Akaike Criterion }=20.14472 \\
\text { Schwarz Criterion }=20.62137 \\
\text { Hannan-Quinn Criterion }=16.92991 \\
\rho=-0.57987 \\
\text { Durbin-Watson }=2.358108\end{array}$ & $\begin{array}{r}\text { Standard De } \\
\text { Standard Err } \\
0.969131 \\
\text { P-val }\end{array}$ & $\begin{array}{l}\text { of the } D \\
\text { egressior } \\
=0.870 \\
0.07539\end{array}$ & ariable $=2.4$ \\
\hline
\end{tabular}

Included periods: 2 cross-sectional units

Length of time-series: 4

Source: produced by the authors with EViews 
The GDP AMAZ coefficient of 0.012813 implies that for a $1 \%$ increase in the GDP_AMAZ there is a $1.2813 \%$ increase in the DeforestRate_AMAZ. The POP_AMAZ coefficient of 0.04097 signifies that for a $1 \%$ increase in the POP_AMAZ there is a $4.097 \%$ increase in the DeforestRate_AMAZ.

Another very important aspect may be observed in the AareaDef'd coefficient of 0.035297 , which generated a growth in the DeforestRate_AMAZ of $3.5297 \%$. The CattHerd_AMAZ coefficient of 0.031135 produces a $3.1135 \%$ increase in the DeforestRate_AMAZ.

The coefficient of determination $\left(R^{2}\right)$ of 0.9691 signifies that around $96.91 \%$ of the variations in the DeforestRate_AMAZ are explained by the variations of the explanatory variables. The $\mathrm{F}$ statistic of 5.99 , statistically significant at a $5 \%$ probability of error (the critical $F$ with ( 5 and 8 ) degrees of freedom $(D F)=5.99)$ indicates that the proposed regression is adequate for the studied phenomenon.

Finally, the Durbin-Watson (DW) statistic of 2.358108 indicates no autocorrelation. The signs of the partial coefficients are consistent with the hypotheses.

Analysis of the regression results of the random effects statistical-econometric panel model

Table 4 reveals that the partial regression coefficients of the random effects panel model are statistically different from zero ata $5 \%$ probability of error.

The partial coefficient of GDP_AMAZ of 0.00006860 signifies that for a rise of up to $1 \%$, for example, of the GDP_ AMAZ implies a $0.006860 \%$ increase in the DeforestRate_AMAZ. Moreover, the partial coefficient of POP_AMAZ of 0.0001997 indicates that for a $1 \%$ increase in the POP_AMAZ there is a $0.01997 \%$ increase in DeforestRate_AMAZ.

On the other hand, the AreaDef'd_AMAZ partial coefficient of 0.0004412 implies that for a $1 \%$ increase in
AreaDef'd AMAZ there is a $0.04412 \%$ increase in DeforestRate_AMAZ; the partial coefficient of the CattHerd_AMAZof 0.0004730 signifies that for a 1\% growth of the CattHerd_AMAZthere is a $0.04730 \%$ increase in theDeforestRate_AMAZ.

The regression coefficient of determination $\left(R^{2}\right)$ of the random effects panel model is 0.7933 . This signifies that $79.33 \%$ of the variations in the DeforestRate_AMAZ are statistically explained by variations in the explanatory variables.

Furthermore, the F statistic $(5,8)$ of 6.14 is statistically significant at a $5 \%$ probability of error (the critical $F$ with $(5,8)$ degrees of freedom $(D F)=2.85)$, because the calculated value of the statistic $F$ is greater than its critical value.

It should be noted that the signs of the partial coefficients of the regression of the statistical-econometric random effects panel model are consistent with the hypotheses. The coefficient of determination $R^{2}=0.7933$ signifies that the regression is adjusted, i.e., $79.33 \%$ of the annual deforestation rate throughout the states is explained by the changes in the explanatory variables. And, therefore, the statistic of the asymptotic Chi-Square test of $\mathbf{8 . 8 0 6 0 4}$ is significant at a $5 \%$ probability of error.

The z-test statistic of 0.6334 is significant at a $5 \%$ probability. The Hausman test of 0.2603 demonstrates that there is a statistically significant difference between the fixed effects and random effects panel estimators at a 5\% probability of error. This implies a rejection of the null hypothesis that the annual rate of deforestation in the Amazonian states is not caused by the explanatory variables used in the model.

Last, but not least, the Durbin-Watson (DW) test, which measures the positive serial correlation of residuals, equal to 1.971962 is less than the DW $=2.000000$, thereby indicating the presence of a correlation in the residuals.

Table 4 - Regression Results of the Random Effects Panel Model

Dependent Variable: DeforestRate_AMAZ

\begin{tabular}{l|c|c|c|c}
\hline Explanatory Variables & Coefficient & z-Test & Standard Error & P-value \\
\hline Constant & 3.950315 & 0.78 & 5.0547990 & 0.457 \\
GDP_AMAZ & 0.006860 & 0.49 & 0.0000139 & 0.634 \\
POP_Amaz & 0.001997 & 1.12 & 0.0017833 & 0.295 \\
AreaDef'd_AMAZ & 0.004412 & 1.33 & 0.0033138 & 0.224 \\
CattHerd_AMAZ & 0.004730 & 0.72 & 0.0000654 & 0.491 \\
& & & & \\
\hline
\end{tabular}

$\mathrm{R}^{2}=0.7933$

$F(5,8)=6.14$

Prob $>\mathrm{F}=0.0126$

Root-mean-square error $(\mathrm{RMSE})=608.12$

Asymptotic Test Statistics: Chi-Square $(5)=8.80604$

z-Test $=0.633445$

Hausman Test: Chi-Square (1) $=0.260677$

Durbin-Watson $(\mathrm{DW})=1.971962$

Source: produced by the authors with EViews 


\section{Final Considerations}

The present article has presented the main concepts of mode of production and mode of extraction, and the relationships that exist between them from an economic viewpoint. It may be observed that industrialised countries are heavily dependent on natural resources from regions with an abundance of resources, such as the Brazilian Amazon.

In general, deforestation in the Amazon may lead to the depletion of the depredated natural resources, which mayin turn increase the likelihood of impoverishing both the soil and local populations. From the outset, it must be understood that the monetary costs that result from man's exploitation of natural resources begin with deforestation. However, in addition to these monetary costs, there are the additional costs that result from the devastating human action on the local environment of social groups that make a living from extractivism in general. This comes from the simple fact that (physical) economics is a heat dissipating structure that is sustained by a metabolic flow from the base of the environment. Indeed, the flow of production begins with the depletion of natural resources of low environmental entropy and continues in the processes of production and consumption of goods. It ends with the return of an equivalent amount of high entropy polluting waste resulting from the destruction of the region's natural resources.

It has also been observed that the rate of deforestation in the Amazon rainforest is primarily responsible for the destruction of its natural resources, especially as the rate of deforestation in the region is directly affected by the following factors: increased GDP, i.e., an improvement in economic growth; a growth in the deforested area and the population and, mainly, an increase in the effective cattle herd in border areas.

Given the socioeconomic awareness regarding the need for environmental preservation, there is a need to act so that care for the environment is a constant objective, especially when protecting nature conflicts with issues related to the socioeconomic development of the population.

The main conclusion, based on the statistical econometric models used, is that most of the explanatory variables were significant at a $5 \%$ probability. On the other hand, the z-test result of the random effects panel model was significant at a $5 \%$ probability of error. Hausman's test suggests choosing the random panel model due to the robustness of the results.

Finally, it may be argued that panel models are undoubtedly useful statistical and econometric tools for comparing time series and cross-sectional model results. Consequently, it may be perceived that the main statistical econometric regressors associated with the rate of deforestation in the states of Amazônia Legal are significant driving forces of this constant problem in the region. However, it cannot be denied that the exploitation of beef cattle production on extensive planted pasture remains one of the main rural activities responsible for the increase of forest deforestation in the vast territory of the Amazon.

\section{References}

Altvater, E. (1995). O Preço da riqueza. São Paulo, Universidade Estadual Paulista.
Banco Mundial. (1992). Relatório sobre o desenvolvimento mundial 1992: Desenvolvimento e meio ambiente. Rio de Janeiro, FGV.

Bunker, S. G. (1985). Underdeveloping the Amazon: Extraction, unequal exchange, and the failure of the Modern State. EUA, University of Illinois Press.

Bunker, S. G \& Ciccantell, P. (1994). The evolution of the world aluminum industry. In: Barham, B., S. Bunker and D. O'hearn (eds.). States, firms and raw materials. The world economy and ecology of aluminum. Madison, WI: University of Wisconsin Press.

Cameron, A. C. \& Trived, P. K. (2005). Microeconometrics: Methods and Applications. Cambrige, EUA, Cambridge University Press.

Cameron, A. Colin \& Trivedim, Pravin K. (2007). Microeconometrics Using Stata. Revised Edition: Stata Press.

Carvalho, André Cutrim. (2012). Expansão da Fronteira Agropecuária e a Dinâmica do Desmatamento Florestal na Amazônia Paraense. Campinas, SP. Tese de Doutorado - Universidade Estadual de Campinas, Instituto de Economia.

Carvalho, André Cutrim \& Lopes, L. O. C. (2017). Fronteira, Instituições e Desmatamento na Amazônia Paraense: uma Perspectiva de Debate através do Novo Institucionalismo Econômico. In: Luís Otávio do Canto Lopes; Marise Teles Condurú, Mário Vasconcellos Sobrinho. (Org.). Gestão Ambiental na Amazônia: território, desenvolvimento e contradições. 18ed. Belém-PA: NUMA/UFPA, v. 18, p. 26-64.

Commoner, Barry. (1972) The Environmental Costs of Economic Growth. In: Robert Dorfman e Nancy Dorfman (orgs). Economics of the Environment Selected Readings. (2 nd ed.). New York, W. W. Norton e Company Inc.

Daly, H. \& Farley, J. (2004). Economia ecológica: Princípios e aplicaçõe. Lisboa, Instituto Piaget.

Da Silva, E. L. \& Menezes, E. M. (2005). Metodologia da pesquisa e elaboração de dissertação, UFSC, 4 ed. Atual. Florianópolis.

Day, K. \& Grafton, R.Q. (2001). Economic growth and environmental degradation in Canada. In: K, Banting, A. Sharpe and F. St-Hilairem (Eds). The Review of Economic Performance and Social Progress, The Longest Decade: Canada in the 1990. Institute for Research on Public Policy and the Center for Studey of Living Standards: Montreal, p.293-309.

Georgescu-Roegen, N. (1969). Process in farming versus process in manfacturing: a problem of balance development." In: Papi, U.; Nunn, C. (Ed). Economic Problems of Agriculture in Industrial Societes. Londres, Macmillan. 
Gil, A. C. (1991). Como elaborar projetos de pesquisa. São Paulo: Atlas.

Grafton, R. Q.; Adamowicz, W.; Dupon, D., Nelson, H.; HILL, R. J. \& Banzetti, S. (2004). Economics of the environment and natural resources. Oxford, UK, Blackwell Publishing Ltda.

Greene, William H. (1997). Wooldridge, J. M. (3nd ed.). Prentice Hall.

Food and Agriculture Organization of the United Nations FAO. (2013). FAO statistical yearbook 2013 world food and agriculture. Food and Agriculture Organization of the United Nations, Romep. 307.

Instituto Brasileiro de Geografia e Estatística-IBGE. (2018) Pesquisa Pecuária Municipal - PPM. Brasil: IBGE-PPM, $2018 . \quad$ Recovered of https://sidra.ibge.gov.br/pesquisa/ppm/quadros/bra sil/2018.

Instituto Nacional de Pesquisas Espaciais - INPE. (2014). Projeto de Monitoramento do Desmatamento na Amazônia Legal por Satélite (PRODES). Brasil: INPE, $2014 . \quad$ Recovered of: http://www.obt.inpe.br/OBT/noticias/inpeconsolida-7-536-km2-de-desmatamento-na-amazoniaem-2018.

Kolstad, Charles D. (2000). Environmental Economics. New York : Oxford University Press.

Kuznets, S. (1974). Teoria do crescimento econômico moderno: Taxa, estrutura e difusão. Rio de Janeiro, Zahar.
Lakatos, E. M. \& Marconi, M. de A. (1991). Fundamentos de metodologia científica. São Paulo: Atlas.

Lira, S. R. B. (2007). Morte e Ressurreição da SUDAM: Uma análise da decadência do padrão de planejamento regional na Amazônia. Belém, NAEA/UFPA.

Mishan, E. J. ( 1969). The Costs of Economic Growth. Ringwood; Vic, Pinguin Australia.

Muller, C. C. (2007). Os economistas e as relações entre sistema econômico e o meio ambiente. Brasília, Universidade de Brasília.

Nikiforos, M. (2004). Distribution-led growth in the long run. Workin Paper, $N^{\circ}$ 814. New York, Levy Economics Institute.

Santiago, A. A. (1970). Pecuária de corte no Brasil central. São Paulo, Secretaria da Agricultura.

Solow, R. (1975). Intergeneration Equity and Exhaustible Resources. Review of Economic Studies. Symposium Volume, p. 29-45.

Stock, James H. \& Watson, M. W. (2004). Econometria. São Paulo, Addison Wesley.

Wooldridge, J. M. (2002). Econometric Analysis of Cross Section and Panel Data. Cambridge: MIT Press.

Wooldridge, J. M. (2010). Econometric Analysis of Cross Section and Panel Data. (2nd ed.). Cambridge: MIT Press.

Wooldridge, J. M. (2006). Introdução à Econometria: uma abordagem moderna. Learning. 